\title{
ПОЕТИКАТА НА СЛЕМ-ПОЕЗИЈАТА
}

\author{
Славчо Ковилоски \\ Универзитет „Св. Кирил и Методиј“, Скопје \\ slavcho.koviloski@outlook.com
}

Во текстот се осврнуваме на слем-поезијата како изведбен начин на презентирање на литературата. Слем-поезијата најчесто се изведува на Потери слем-натпревари, фестивали и други настани и е производ на урбаноста и на урбаниот начин на живот, а врз неа се чувствува влијанието на хипхоп-музиката. Мешавината на слем-поезијата со хипхопот и со други форми на изразување, особено кај помладите, придонесува за менување или за подобрување на односот кон поезијата и перформативните уметности. Слем-поезијата посочува проблеми и проблематизира одредени веќе постојни и општо прифатени ставови и состојби, а критички се осврнува и укажува на непосакувани тенденции во општеството. Техниките на создавање слем-поезија, кои се сметаат за релевантни, се однесуваат на структурата, јазикот, афектот и значењето. Функционирањето на слемот се одвива преку јазик што располага со сопствена терминологија и има своја поетика. Структурно, стиховите можат да бидат со рима или без неа, организирани во строфи, со интерпункциски знаци или без нив. Посебно внимание се посветува на мелодиката и на ритамот, кои умешниот интерпретатор ги користи за акцентирање и за потенцирање на стиховите што смета дека се важни за настапот. Со нејзината жива и разиграна интерпретација, ослободена од класичните сфаќања за поезијата како жанр, слем-поезијата и Поетри слем-манифестациите поттикнуваат нови генерации поети на кои им се овозможува да ги споделат своите ставови пред поширока публика.

Клучни зборови: Поетри слем, изведбена поезија, слемер, хипхоп, стилски фигури 


\title{
THE POETICS OF SLAM POETRY
}

\author{
Slavčo Koviloski \\ Ss. Cyril and Methodius University, Skopje \\ slavcho.koviloski@outlook.com
}

In this text we refer to slam poetry, as a performing way of presenting literature. Slam poetry is most often performed at Poetry slam competitions, festivals and other events. It is a product of urbanity and urban lifestyle and is influenced by hip hop music. The mixture of slam poetry with hip hop and other forms of expression, especially among the younger population, contributes to changing or improving the attitude towards poetry and the performing arts. Slam poetry points out problems and problematizes certain already existing and generally accepted attitudes, conditions, and critically addresses the undesirable tendencies in the society. The techniques of making slam that are considered relevant refer to the structure, language and meaning of slam poetry. Slam functions through a language which has its own terminology and has its own poetics. Structurally, the verses can be rhymed or free, organized in stanzas, with or without punctuation. Special attention is paid to the melody and rhythm that the skilled performer uses to stress and emphasize the verses that they consider important for their performance. With its lively and playful interpretation, free from the classical notions of poetry as a genre, slam poetry and Poetry slam manifestations inspire new generations of poets who are enabled to share their views with a wider audience.

Keywords: Poetry Slam, spoken word, hip-hop, slammer, figures of speech 


\section{1 Игра со зборот и со телото}

Вообичаено, за слем-поезијата се мисли како за производ на новиот милениум, но ваквото размислување е далеку од вистината. Нејзините почетоци ce наоѓаат во првата половина на 80 -тите години на XX век, иако дури во 90 -тите години слемот поинтензивно проникна во пошироките поетски кругови и во академските средини ширум светот. Од организирањето на првиот поетски слем-настан во Чикаго (1984) од страна на Марк Смит, преку Сан Франциско и Бостон, до Њујорк, благодарение на основните карактеристики на слем-поезијата, како што се: перформативноста, гласноста, драматичноста, слободниот стил на изразување итн., таа набрзо се прошири низ светот. Денес слем-поезијата се изведува на фестивали онаму каде што постои поетска традиција, што значи - секаде.

Во основа, слем-поезијата или слемот е дел од „натпреварување“ во кое поетите настапуваат пред публика, која со извици решава кој е победникот. Бидејќи во литературата на англиското говорно подрачје повеќепати е објаснет начинот на кој функционираат овие слем-фестивали и перформанси, ние ќе се задоволиме со наведување само уште на двата вида слем-натпревари кои се најчести: „отворен слем“ („опен-слем“: „Open Slam“), каде што може да учествува кој било до пополнување на одредениот број слободни места, и „слем со покани“ („инвитејшнал слем“: „Invitational Slam“), каде што учесниците се повикани да бидат дел од натпреварот. На национални натпревари за победникот одлучува и жири-комисија, која се состои од пет судии, додека во помалите - најчесто се три члена. Откако секој поет ќе го заврши својот настап, секој судија доделува бод, оценувајќи го настапот. Скалата на бодување најчесто се движи од 0 до 10 бода (Williamson 2015: 2-3). Во оценувањето на настапот голема улога има и реакцијата на публиката.

Како што може да се види, слемот е сосема поразличен од вообичаените поетски читања, како по ставот на изведувачот така и по начинот на изведување, темите што се обработуваат и јазикот што се употребува. Додека при традиционалното поетско читање најчесто се зазема некаков стоички став или, пак, во рецитирањето се вклучуваат и одредени движења на рацете и на нозете, слем-поезијата е поагресивна, пожива, поподвижна, па на моменти и погруба во однос на стариот начин на интерпретирање на стиховите. Во социолошка и во културолошка смисла на зборот, се однесува на она што се нарекува „култура на младите“, иако денес во овие натпревари и читања се вклучени голем број припадници од постарите генерации.

Македонската поетска слем-сцена во голема мера ги задоволува и ги исполнува критериумите на поетските слем-манифестации, како и самиот пристап на создавање и изведба на слем-поезијата. Неколкуте слем-фестивали, кои се одржуваат во Тетово, во Скопје и во Прилеп ја негуваат формата на поетри слемот, со настапи на изведувачи од кои се избираат македонски претставници на поголемите поетри слем-натпревари во Европа. Меѓутоа, иако бројот на натпреварувачи е сосема задоволителен, се чини дека има простор за зго- 
лемување и за унапредување на квалитетот на презентираната слем-поезија, како во начинот на изведбата така и во шареноликоста на одбраните теми и во употребата на стилските фигури.

Како најспецифични особености на слем-поезијата ќе ги издвоиме: широкиот радиус на гласови при изведбата, разновидните пристапи при пишувањето на текстовите и нивното изведување, со што се произведуваат различни стилови на интерпретација. Истовремено, тие во многу нешта зависат и од културната традиција на поширокиот круг на изведба: местото, времето, јазикот. На таков начин слем-поезијата може да се поврзе и со усната поезија, специфика на минатите времиња, почнувајќи уште од антиката (Ковилоски 2019: 14). Сепак, иако можеме да се навраќаме назад во времето барајќи сличности и правејќи споредби со поетски појави од минатото, слем-поезијата е производ на урбаноста, на урбаниот начин на живот и влијанието на хипхоп-музиката. Без разлика дали користат или не користат рими, слем-поетите ги користат можностите што ги нуди урбаната култура: играње со гласот, кореографија, драмски настап (стенд-ап), битбокс итн. Уметничкиот перформанс на слем-поетите на поетри слем-манифестациите во себе вклучува повеќе сегменти на уметностите, како музика, поезија и театар. Тесната врска со хипхоп-културата се согледува во едноставниот факт што од изведувачот на слем-поезијата се бара да биде „господар на церемонијата““ или МЦ (МС, односно: Master of Ceremony), целосен владетел на времето и просторот што го опкружува за време на неговиот настап. Тој мора да ги покаже своите ораторски и драмски вештини за да ѝ го привлече и да ѝ го одржи вниманието на публиката.

Од друга страна, покрај ваквите отворени определби, укажувања, категоризирања и согледувања на слем-поезијата, се отвораат и се анализираат прашања што навлегуваат во амбиенталната структура на самиот слем. Овие анализи и согледби се повеќе од академски карактер и се занимаваат со проблеми што во себе вклучуваат прашања како што се влијанието на „црната култура“, односно на афроамериканската култура врз слемот, културните политики во градењето на идентитетите, културната политика на слем-поезијата, врските на џезот и хипхопот со слемот, расната политика, станувањето мејнстрим, освежувањето и враќањето на поезијата од маргините кон пошироката публика и конечно слем-поезијата како жанр. Широката палета на прашања поврзани со културните и со социоекеномските односи значи актуализирање на прашања од секојдневието, но овој пат преку уметнички изразни средства. Можноста поезијата да им се приближи на оние што немаат или имаат сосема мали шанси да се занимаваат со литература е еден од успесите кои треба да ѝ се припишат на слем-поезијата. Слично како и со хипхопот, извлекувањето на најдоброто од авторите што живеат на најлошите места и дадената можност своите лирски капацитети да ги претстават пред публика желна да чуе нешто ново, е само еден многу мал, но значаен дел што го обезбедува слемот. Притоа, стиховите и настапите можат да звучат грубо за нечии уши, да предизвикаат револт, да не се политички коректни, но во суштина, таква е слем-поезијата.

Во одредена смисла, слем-поезијата би можела да се нарече авангардна, а такво мислење се среќава и кај Смит и Крајнак (Smith and Kraynak 2009: 
153). Во многу нешта слемот има допирни точки и со натурализмот, со експресионизмот и со импресионизмот. Главно, тие се однесуваат на отпорот кон книжевната традиција, со нагласка за исклучителната важност на изразот, со идеја „за слободно прифаќање на сите сетилни впечатоци“, со отфрлање на идејата за општа убавина и ,залагајќи се за силата на изразот кој ги крши сите конвенции и се појавува како извик, како крик и како духовен облик на чиста потреба за изразување“ (Solar 2011: 176). Меѓутоа, треба да се нагласи и тоа дека ваквата своевидна еклектичност исполнува само дел од принципите и начелата на слемот.

Мешавината на слем-поезијата со хипхопот и со други форми на изразување, особено кај помладите, придонесува за менување или за подобрување на односот кон поезијата и кон перформативните уметности. Ослободени од класичните сфаќања за поезијата како жанр, слемот поттикнува нови генерации поети на кои им се овозможува да ги споделат своите ставови пред пошироката публика. Тој посочува проблеми и проблематизира одредени веќе постојни и општо прифатени ставови и состојби, а критички се осврнува и укажува на непосакувани тенденции во општеството. Амбиентот на отуѓувањето, осаменоста, повредувањето и сл. откриваат низа проблеми во меѓучовечките односи, кои се рефлексија на современиот социјален живот и општествените услови на живеење. Оттука, некои стихови можат да зазвучат како порака и како предупредување, како своевиден крик на кој треба да му се обрне посебно внимание: „Џои секогаш ми велеше, смеејќи се, како тоа / всушност да е шега, дека сакал / да се самоубие, но никогаш не било вистинското / време“ (Hilborn 2015: 7). Се разбира, покрај позитивните постојат и негативни страни, како што умеат да забележат критичарите на слемот, па така, она што на некои им се чини како унапредување на јазикот, други го квалификуваат како подигрување со него или, во крајна мера, дури и како непрепознавање на стандардниот англиски јазик, како што е случајот со афроамериканските автори (Sherman 1997; Ковилоски 2019б: 12). Понатаму, можните пцости, слободниот стил на изразување и темите што ги обработуваат, некои ги квалификуваат како невкус, неприпадност кон поезијата, но и неприпадност кон театарот, злоупотребување на дадениот простор за да се проговори за минорни проблеми што не таргетираат поширока публика итн. Во секој случај, на слем-поезијата треба да се гледа како на нов правец во литературата, со свои особености, за кои подетално ќе зборуваме во продолжение.

\section{2 Терминолошки одредници}

Терминолошки, слем-поезијата го оправдува значењето што го даваат некои од најголемите речници (Meriam-Webster, Cambridge, Oxford), а тоа е назнаката за бучност, гласност, критикување, како и живост и непредвидливост. Дури и во речниците на сленг, терминот слем останува термин за бучава, но и за навреда (Watts 1994: 232). Ова објаснување, кое определува дел од основите на слем-поезијата нѐ доведува до заклучокот дека за слемерот (интерпретаторот на слем-поезија), покрај напишаните зборови, од суштинско значење е и неговата усна интерпретација и односот што ќе го воспостави со публиката. 
Иако оваа поезија е базирана врз гласност, таа не треба да биде празна бучава, туку концентрирана сила на говорот, која, кога е потребно, наменски се употребува и го олицетворува самиот слемер. Гласноста не е само празен вик туку и крик со емоции, кој, доколку е правилно искажан и употребен, кај публиката треба да предизвика реакции. Емоциите при интеракцијата на интерпретатор - публика можат да се покажат како најважна алка за придобивање на жирито и победа на натпреварот, но и за понатамошни признанија на слемерот.

Перформативната, односно изведбената поезија (spoken word poetry), каква што е слемот, често пати знае да биде контроверзна поради гласноста, но и поради радикалноста на содржината на текстовите. Поради драматуршките елементи, поради гримасите, движењата на телото и денешните можности за снимање видеозаписи, таа е дел и од виралниот свет, споделувајќи се на социјалните медиуми. На тој начин, уште повеќе се шири и се добива на внимание меѓу различни генерации поети. Овој, да го наречеме, крик против установеното академско разбирање за начинот на создавање и објавување песни, разбирливо може да предизвика негирање на естетските вредности на слемот.

Сепак, од друга страна, без двоумење можеме да кажеме дека слем-поезијата ја намалува бездната меѓу поетот и публиката. Слемерот директно му се обраќа на слушателот и фактички го вклучува во својот перформанс. Слушателот, пак, ги восприема неговите зборови, го охрабрува, му испраќа повратни вибрации и така во круг. Воспоставениот мост меѓу бучниот изведувач и бучниот слушател значи воспоставен мост меѓу авторот и неговиот консумент. Поради тоа, треба да се има на ум дека во зависност од тоа дали е изведена од авторот или читателот ја чита самиот, една иста песна може да звучи различно или да биде сфатена во друг контекст.

Функционирањето на слемот со натпреварите, фестивалите, настапите, интерпретирањето итн., се одвива на јазик што располага со сопствена терминологија, која во одреден дел е сленговска, а дел е позајмена и од хипхопот (значи, од афроамериканско потекло). Основните термини што најчесто се употребуваат, меѓу другите се: Spoken Word, Spoken Word Artist, Slam poetry, Poetry Slam, Slam, Slam Poet, Slammaster итн. Објаснувањата за нив се универзално признати и се употребливи во голем број земји, без разлика што му припаѓаат на англискиот јазик. Така, на пример, Spoken word е начин на изведување поезија со афроамериканско потекло, а денес се смета за дел од слем-поезијата. Оттаму произлегува и терминот spoken word artist, односно човек што рецитира, говори, изведува поезија. Slam poetry (или понекогаш само slam) означува слем-поезија (или слем) и треба да се прави разлика од Poetry Slam, кој го означува настанот, односно натпреварувањето на кое се изведува слем-поезијата. Co Slammaster се означува човекот што настапува, односно тој е „господарот на церемонијата“" на Poetry Slam-от (MC во хипхопот, оној што рецитира). Slam Poet е оној што пишува и изведува слем-поезија (на македонски: слемер) итн. Навистина, постојат повеќе именувања, кои се преземаат директно од туѓојазичните средини и се употребуваат во светот на слем-поезијата. Понекогаш тие лесно се адаптираат во речникот на слемерите (уште еден термин приспособен за потребите на македонските слем-поети), како на пример: Поетри слем, слем поет, слем. Од друга страна, постојат тер- 
мини чие присуство во неанглиското говорно подрачје потешко наоѓаат примена или, пак, воопшто не можат да се употребат. Како пример ќе ги наведемe: to kick, што соодветствува со фразата од рап-музиката 'да се каже рима, да се настапи'. Таков е случајот и со зборот ріесе, што буквално значи „парче“, а во случајов станува збор за означување на самата песна.

Токму затоа, повторно се навраќаме и на терминолошката определба на слемот, односно на перформативната, т.е. на изведбената природа на оваа поезија. Она што во англиското говорно подрачје се нарекува spoken word poetry, во некои од другите јазични средини едноставно се презема како такво - со англискиот термин (Германија, Хрватска, Турција, Шпанија). Во други јазични средини се изнаоѓаат решенија што најблиску ја отсликуваат суштината на овој термин, па така, во Португалија се нарекува recitação (или récita и declamação), во Русија - художественная декламация, во Украина - художнє читання, во Словачка - hovorené slovo. Во македонското јазично подрачје јавните настапи се определуваат како реч и слово. Сепак, за потребите на конкретниот вид уметнички перформанс, односно spoken word poetry, ние го предлагаме терминот - изведбена поезија.

\section{3 Структура и форма}

Техниките на создавање слем-поезија што се сметаат за релевантни, се однесуваат на структурата, јазикот, афектот и значењето. Школските примери во кои професорите им ги посочуваат овие елементи на своите студенти, при пишувањето во себе вклучуваат низа прашања што треба да се одговорат. Притоа, тие се водат според воспоставените правила од теоријата на поезијата што се однесуваат на версификацијата (метриката), стилските фигури (фонолошки, синтаксички, семантички и логички) и интерпретацијата на повеќе нивоа (фонолошко, морфолошко, прозодиско итн.). Се разбира, авторот нив може да ги употреби по подолго временско слушање, читање, пребарување и осмислување на стиховите. Исто така, нив може да ги употреби и ненамерно, благодарение на слухот, на звучноста, на поентата што сака да ја постигне. На крајот на краиштата, сето тоа може да стане неважно; важен е само крајниот производ.

Структурно, стиховите можат да бидат со или без рима, организирани во строфи, со или без интерпункциски знаци. Посебно внимание се посветува на мелодиката и на ритамот, кои умешниот интерпретатор ги користи за акцентирање и за потенцирање на стиховите што смета дека се важни за настапот. Во ваквата жива и разиграна интерпретација, цезурата и паузата ја имаат истата функција како и акцентот. Моментите на повишување на гласот, проследени со нагло стишување и тишина, исто така го потенцираат значењето на кажаното. Често пати наглите резови и паузата при исказот можат да кажат многу повеќе отколку зборовите. Оттука, прозодијата е мошне важен елемент во структурата на слем-поезијата. Нејзината метричко-ритмичка улога, како дел од метриката, е од суштествено значење во организација на темпото, акцентот, интонацијата, ритамот итн. Гласноста при интонацијата на слушателот директно му дава дополнителни информации, додека, пак, читателот нив 
треба самиот да ги доживее. Таа функција при напишаните песни ја имаат интерпункциските знаци, кои утврдуваат дали авторот прашува, извикува, поставува реторско прашање или ја завршува реченицата.

Секоја слем-песна има свое темпо. Брзината на изговорот зависи од должината на стиховите. Општото правило дека долгите стихови имаат побавно темпо не се потврдува во слемот. Поради потребите за динамичност, кои оваа поезија ги фаворизира, обично се избегнуваат премногу долгите и сувопарни рецитирања. Комбинирањето на кратки и долги реченици и стихови, со паузи и цезури на крајот и меѓу полустиховите, е честа постапка. Се комбинираат и метричкиот (античкиот), силабичкиот и тонскиот (акцентскиот) систем. Можноста за вакви комбинации зависат од јазичните особености на говорното подрачје од кое потекнува интерпретаторот.

Слемот е политички „некоректен“ жанр, а ублажувањето на зборовите со еуфемизми што означуваат едно исто и не е толку пожелно. Слично како и во обичниот говор, слемот се обидува да го презентира секојдневието, во кое кавгата меѓу одредени лица наместо со: „Одлетај како птица и исчезни во облаците“, вообичаено завршува со пцост, колнење или други погрдни сленговски/улични изрази: „Марш да не те гледам!“, „Оди цркни!“, „Да идеш у три лепе...“ и сл. Оваа „потенцијално контроверзна природа““ на слемот, како што забележале професорите што го истражувале слемот (Low 2011: 64), во голема мера може да го опушти изведувачот пред и за време на неговиот настап, а во иднина дури и да го поттикне кон подетално теориско изучување на литературата, па дури од него да направи и „вистински“ писател (поет, прозаист, драматург).

Пејоративната лексика што може да биде употребена не се употребува за етнички групи или религии, туку на состојби, групи или индивидуалци во општеството, кои на некаков начин слемерот ги идентификува како неподобни и погрешни. Еден таков пример може да употреби авторка што негодува против некое момче во љубовните слем-песни, при што момчето може да биде: „мамино галениче“, „фуфица“, „плачко“, а во контекст на темата да му се посочи да оди да поплаче кај мајка му, „да се закачи на цицката на мајка му“, „да си го гушне мечето“, „да се пикне под маса како кучка“ и сл. Наведените примери не се извадоци од конкретна поезија, туку претставуваат еден воопштен преглед на изразите што можат да се употребат во слемот, а кои некои можат да ги сфатат за навредливи.

Слем-поезијата изобилува со стилски фигури. Најчесто ги сретнуваме: метафората, иронијата, епитетот, метонимијата, елипсата, симболот, хиперболата, компарацијата итн. Забележливо е присуството на стилските фигури со кои се игра со звуци и се игриви, како на пример ономатопејата, анафората, епифората, асонанцата и сл. (Ќулавкова 2007). Зборовите, односно стиховите се употребуваат рационално, бидејќи секое отскокнување од воспоставениот ритам и тема може да го забави темпото, да доведе до нарушување на ритамот и на разводнување на делото. Во одредени случаи, внимателно одбраните „полабави“ стихови не само што не го нарушуваат квалитетот на песната туку можат и да ѝ дадат дополнителен „шмек“ на мислата. Оттука, можеме да го 
изведеме заклучокот дека стилските фигури се од значење и ја поддржуваат изведбеноста на слем-поезијата.

Слем-поезијата целосно се вклопува во идеите што ги изложува Јуриј М. Лотман, при што се утврдува дека уметничкото дело е „модел на стварноста“ и има „комуникативна функција“. Ако е така, слем-поезијата е вистински претставник на новата поетика, на модерната поетика, на поетиката на XXI век. Ритмичките повторувања, акцентирањата и употребата на гласот како инструмент, музички, образовен, дидактички, шегобиен, доведува до прашањето за метричките повторувања, кои се поставуваат на класификациска, статистичка и функционална површина. Како што утврдил Лотман, од нив произлегуваат низа потпрашања: „Каква е нивната структурна улога? Каква функција имаат во општиот склоп на текстот?“, при што додава: „Умесно е не само да се постави прашањето: 'како е организиран текстот во ритмички поглед?', туку и: 'зошто е тој така организиран?'“ (Лотман 2005: 177).

Токму тука внимателниот читател ќе ја сфати потребата од херменевтиката. Кога велиме внимателниот читател, главно мислиме на истражувачот што студиозно сака да се посвети или веќе се посветил на анализа на одредени песни, автори и теми. Инаку, вообичаено, пасионираниот читател и слушател на слемот ги забележува овие стилски форми, но нив ги сфаќа како нешто природно, без да го оценува местото каде е употребена градација, а каде компарација. За него најважен е течниот и разбирлив редослед на зборовите и речениците. Колку е поритмичен текстот, толку подобро. Линеарниот текст и линеарната изведба на слем поезијата ја смирува и ја умртвува публиката и читателот: сосема спротивно од целите на слемот. Во таквите случаи, а нив секако дека ги има, песната не допира до оние до кои е наменета, а слемерот го губи вниманието и авторитетот. Во таа смисла, поетиката на слем-поезијата е во уметничката композиција и нејзината интерпретација пред широкиот аудиториум.

На неа се надоврзуваат и темите што се обработуваат. Тие се од широк дијапазон. Сепак, изборот на вистинска тема е многу потежок избор отколку што изгледа на прв поглед. Авторот треба да ги доживее или барем да може да се најде во ситуациите за кои пее. На пример, доколку потекнува од богато семејство, а сака да ги опише тешкотиите на бездомничкиот живот, тоа ќе биде многу потешко. Оттука, првиот чекор што треба да се направи во создавањето пристојна слем-песна е одбирањето вистинска тема. Во прилог ке наведеме некои од темите што најчесто се употребуваат при пишувањето: стапување и одржување љубовна врска, социјални прашања, еротика, фантазија и сон, расни и идентитетски прашање, споделување искуства од минатото, опис на моментните чувства во однос на секојдневието, семејството, пријателите, употреба на дрога, размислувања за непостоење на разум, разумот воопшто, односи во семејството, чувство на жалење, религија, бес и фрустрации, одредени настани што оставиле впечаток и сл. Вакви и други слични теми обработуваат и други масовни медиуми, кои во основата ја имаат перформативноста.

Според Сузан Сомерс-Вилет, популарните манифестации на енергичноста при исказот, како што се хипхопот и говорниот збор (spoken word), ги отвораат вратите на преиспитување на односите во општеството и ја надополнуваат 
слем-поезијата. Таа, пак, „користејќи ги културните рубрики на расата и идентитетот, неспорно и фундаментално ги промени односите меѓу американската популарна публика и поезијата“" (Somers-Willett 2009: 25). Овие праобрасци, како хипхопот и говорниот збор, можат да се препознаат во колективните манифестации како Поетри слемот, како и во мотивите што произлегуваат од индивидуалните стремежи за јасно и гласно (!) обелоденување на надворешните потиснувања и на внатрешните борби на авторите (Алекс Данг, Тејлор Мали, Биг Папа И, Рејчел МекКибенс, Денис Фроман и др.). Активниот, односно активистичкиот пристап на слемерите, кој во одредена мера ја „демократизира“ поезијата, избавувајќи ја од зачмаените и здодевни поетски практики да се рецитира без да се восприемаат погледите и енергијата на слушателите, може да се сфати како своевиден протест против униформираноста на поезијата.

Оттаму, кога се зборува и се пишува за слем-поезијата, треба да се има предвид дека, иако во западната литература се наоѓаат бројни дела посветени на неа, кај нас допрва ќе се почувствува посилна потреба за посериозен академски пристап кон оваа проблематика. Самото навлегување на слем-поезијата во пошироките поетски кругови, зголемениот интерес за неа, доведува до потреба за нејзино подлабоко и темелно проучување.

Да завршиме со неколку нафрлоци: слемот може да биде сериозен, но и забавен; фрагментиран, но и слеан; искажан на кодифициран јазик, но и на сленг; искажан со јасни и отворени слики, но и со симболи, компарации и параболи; и секогаш како игра: на зборот, на телото, на мислата.

\section{Библиографија}

Ковилоски, С. (2019а). Слем-поезија. Нова Макеоонија, 5 јуни.

Ковилоски, С. (2019б). Лириките на хипхопот. Нова Макеgонија, 12 јуни.

Ќулавкова, К. (прир.). (2007). Поимник на книжевнайа йеорија. Скопје: Македонска академија на науките и уметностите.

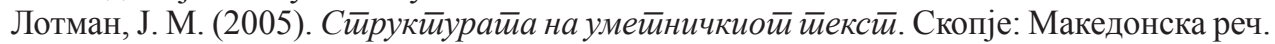

Hilborn, N. (2015). Joey. Our Numbered Days. Minneapolis: Button Poetry, Exploding Pinecone Press.

Low, B. (2011). Slam School: Learning Through Conflict in the Hip-Hop and Spoken Word Classroom. Stanford University Press.

Sherman J. R. (ed.). (1997). African-American Poetry, An Anthology, 1773-1927. Mineola, New York: Dover Publications, Inc.

Smith, M. K., Kraynak, J. (2009). Stage a Poetry Slam: Creating Performance Poetry Events-Insider Tips And Lots of Examples. Sourcebooks MediaFusion.

Solar, M. (2005). Teorija književnosti. Zagreb: Školska knjiga.

Somers-Willett, S. B. A. (2009). The Cultural Politics of Slam Poetry: Race, Identity, and the Performance of Popular Verse in America. The University of Michigan Press.

Watts, Karen (compiler). (1994). $21^{\text {st }}$ Century Dictionary of Slang. New York: Dell Publishing.

Williamson, J. W. (2015). The Hermeneutics of Poetry Slam: Play, Festival and Symbol. Journal of Applied Hermeneutics. 